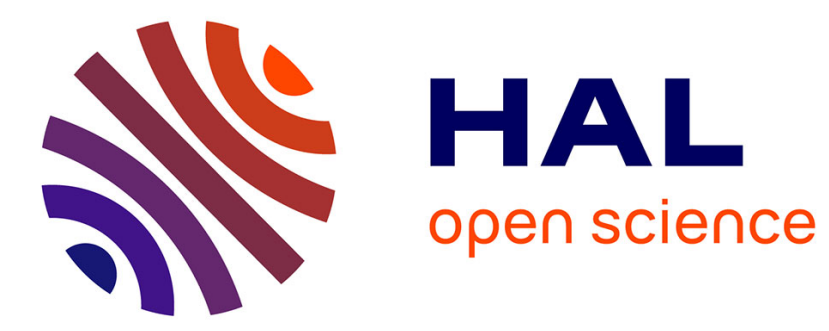

\title{
Multimeric Ionotropic Purinoceptor Detection by Protein Cross-Linking
}

Vincent Compan, François Rassendren

\section{To cite this version:}

Vincent Compan, François Rassendren. Multimeric Ionotropic Purinoceptor Detection by Protein Cross-Linking. Purinergic Signaling, pp.147-153, 2020, 10.1007/978-1-4939-9717-6_10 . hal02395192

\section{HAL Id: hal-02395192 \\ https://hal.science/hal-02395192}

Submitted on 12 Oct 2021

HAL is a multi-disciplinary open access archive for the deposit and dissemination of scientific research documents, whether they are published or not. The documents may come from teaching and research institutions in France or abroad, or from public or private research centers.
L'archive ouverte pluridisciplinaire HAL, est destinée au dépôt et à la diffusion de documents scientifiques de niveau recherche, publiés ou non, émanant des établissements d'enseignement et de recherche français ou étrangers, des laboratoires publics ou privés. 


\title{
Multimeric ionotropic purinoceptor detection by protein cross-linking
}

\author{
Vincent Compan $^{1,2}$ and François Rassendren ${ }^{1,2}$ \\ ${ }^{1}$ IGF, Univ. Montpellier, CNRS, INSERM, Montpellier, France. ${ }^{2}$ Labex ICST
}

\begin{abstract}
Summary
$\mathrm{P} 2 \mathrm{X}$ receptor subunits (P2X1 to $\mathrm{P} 2 \mathrm{X} 7)$ assemble to form trimeric homo- or heteromers. Here, we describe the use of protein crosslinking to study the composition of $\mathrm{P} 2 \mathrm{X}$ receptor complexes. This simple protocol is useful for determining the stoichiometry of P2X heteromeric receptors as well as for assessing the effect of point mutation, truncation or concatenation of the quaternary architecture of these receptors.
\end{abstract}

Key words: P2X, crosslinking, heteromer, homomer, trimer, quaternary structure.

Running title: crosslinking of $\mathrm{P} 2 \mathrm{X}$ receptors

\section{Introduction}

Crosslinking reagents are widely used to elucidate quaternary structure of protein complexes. These compounds create covalent link between proteins that interact or that are in close proximity to each other. These covalent bridges offer a simple method to stabilize complexes and determine molecular weight/stoichiometry of protein 
complexes following SDS-PAGE analysis. Different crosslinkers are commercially available and differ by their chemical reactivity, length of the spacer arm and their ability to cross the plasma membrane (see Figure 1 for an overview of crosslinker features). Homobifunctional N-hydrosuccinimide (NHS) ester represents the most popular class of crosslinkers that forms bridges (cleavable or not) between lysine residues.

In the field of purinoreceptor, cross-linking studies of $\mathrm{P} 2 \mathrm{X} 1$ and $\mathrm{P} 2 \mathrm{X} 3$ receptors assembly provided the first biochemical evidence of the trimeric architecture of P2XR channel [1]. Trimeric architecture of P2XR was finally confirmed by several approaches including atomic force microscopy[2], electron microscopy[3], and the crystal structure of the truncated zebrafish zP2X4R[4].

Thanks to its simplicity and effectiveness, cross-linking strategies still represent a method of choice in structure-functions studies to analyze the effects of truncation or point mutations on the quaternary structure of $\mathrm{P} 2 \mathrm{X}$ receptors[5] [6]. We and other have also employed crosslinkers to elucidate the subunit composition of $\mathrm{P} 2 \mathrm{X}$ receptor complexes. For instance Boumechache et al. demonstrated that in primary culture of microglia and macrophages endogenous $\mathrm{P} 2 \mathrm{X} 4$ and $\mathrm{P} 2 \mathrm{X} 7$ subunits interact between homotrimers rather than within heterotrimers[7]. We demonstrated that P2X5 and P2X2 subunits interact to form heteromeric receptors with alternate stoichiometries, both expressed at the plasma membrane[8].

In this chapter, we will describe a simple protocol that employ NHS ester based crosslinkers to study $\mathrm{P} 2 \mathrm{X}$ receptors assembly and determine the stoichiometry of heteromeric $\mathrm{P} 2 \mathrm{X}$ receptors.

\section{Materials}




\subsection{Expression of the P2X subunits in HEK293 cell line}

1 Transfection reagent Lipofectamine 2000 (Life Technologies) or equivalent can be used to transfect HEK293 cell line.

2 Complete cell media appropriate to the cell line in culture (for example, high glucose DMEM-Glutamax medium with 10\% of fetal calf serum for HEK293).

3 Opti-MEM culture media (Life Technologies).

4 Plasmids coding for the P2X subunits (see Note 1).

\subsection{Cross-linking}

1 Crosslinkers such as BS3, Bis(NHS)PE05, sulfo-NHS-SDA or NHS-SDA (see Note 2)

2 Phosphate-buffered saline containing $1 \mathrm{mM} \mathrm{CaCl}_{2}$ and $0.5 \mathrm{mM} \mathrm{MgCl}_{2}$ (PBS-CM). (see Note 3 )

3 Quenching solution (PBS-CM containing $50 \mathrm{mM}$ Tris $\mathrm{pH} 8.0$ ).

4 UV lamp with $365 \mathrm{~nm}$ bulbs for diazirine based crosslinking (see Note 4).

\subsection{Western blotting}

1 Cell lysis buffer (20 mM HEPES, 100 mM NaCl, 5 mM EDTA, 1\% TX-100, pH7.4, and protease inhibitor cocktail)

2 Tris-glycine gels or equivalent (see Note 5)

3 Appropriate primary antibodies directed to P2X subunits and secondary antibodies.

3. Methods 


\subsection{HEK293 transfection}

1 Cells are plated 24 hours before transfection in 6 well plate to obtain a $60-70 \%$ confluence on the day of transfection.

2 Transfection of HEK293 can be performed using Lipofectamine 2000 according to the manufacturer's instructions using $50 \mathrm{ng}$ of P2X cDNA (see Note 6), $100 \mu 1$ Opti-MEM and $5 \mu 1$ Lipofectamine2000 per well.

3 Incubate cells with transfection mixture for $4-5 \mathrm{~h}$ at $37^{\circ} \mathrm{C}$ and $5 \% \mathrm{CO}_{2}$, then remove transfection reagent containing media and split cells in 12 well plate with fresh culture media.

4 Cross-linking experiments can be performed the following day or $48 \mathrm{~h}$ after transfection.

3.2 P2X multimer crosslinking using homobifunctional crosslinkers BS3 or

\section{Bis(NHS)PE05}

1 Cells are washed twice with ice cold PBS-CM.

2 Incubate cells with the given crosslinker diluted in PBS-CM to a final concentration of 1-5 $\mathrm{mM}$ (see Note 7) for $30 \mathrm{~min}$ at $4^{\circ} \mathrm{C}$ (see Note 8).

3 Cells are washed once with ice cold PBS-CM.

4 Incubate cells in quenching solution (50 mM Tris pH8.0 in PBS-CM) for 5 min at $4{ }^{\circ} \mathrm{C}$

\subsection{P2X multimer crosslinking using heterobifunctional crosslinkers sulfo-NHS-}

\section{$S D A$ and its uncharged analog NHS-SDA}

1 Crosslinking was performed as described above using $2 \mathrm{mM}$ sulfo-NHS-SDA or the membrane permeant analog NHS-SDA. 
2 After quenching the free crosslinkers (step 4 above), cells were exposed to UV light (365 nm) for $15 \mathrm{~min}$ (see Note 9) to induce diazirine group reaction to any amino acid side chain. Keep cell dishes on ice (see Note 8).

\subsection{Visualization of P2X multimer by western Blotting}

1 Cells are scraped in $100 \mu 1$ of CLB per well.

2 Incubate lysates $30 \mathrm{~min}$ at $4^{\circ} \mathrm{C}$.

3 Centrifuge at $16.000 \mathrm{~g}$ for $10 \mathrm{~min}$

4 Keep supernatant and discard pellet

5 Determine protein concentration using BCA method or equivalent.

6 Add appropriate loading buffer (depending on the type of gels selected at step 7) and reducing agent such as 5\% $\beta$-mercaptoethanol (see Note 10).

7 Separate protein by electrophoresis (load $10 \mu \mathrm{g}$ of protein for each condition per lane). and transfer to nitrocellulose membranes.

8 Use appropriate primary and secondary antibodies to visualize P2X homomeric or heteromeric complexes (see figure 2).

\section{Notes}

1 Because most P2X subunits have similar molecular weight, the use of P2X subunits tagged to GFP (or any other fusion protein) might facilitate the analysis of the stoechiometry of heteromeric P2X receptors. Control experiment will have to be performed to confirm that the fusion does not alter the trimeric architecture of the corresponding homomeric $\mathrm{P} 2 \mathrm{X}$ receptors. 
2 Different crosslinkers are commercially available and differ by their i) chemical reactivity (functional groups that bind the protein interest), ii) spacer arm composition (affecting the length and cleavability of the crosslinker) and, iii) solubility (and so their membrane permeability). Homomeric and heteromeric P2X receptors are efficiently crosslinked using homobifunctional N-hydroxysuccinimide ester with spacer arm length between 11 and $22 \AA$ (See Fig.1). We also obtain good results with heterobifunctional crosslinkers that combine NHS-ester and diazirine-based photoreaction chemistries leading to the crosslink of amine-containing molecules with nearly any other functional group via long-wave UV-light activation (Fig1). Most of these crosslinkers have membrane permeable analogs suitable for intracellular conjugation.

3 When using N-hydroxysuccinimide ester based crosslinkers, do not use Tris-buffered solution during crosslinker incubation as Tris contains free amine group that will quench the reaction.

4 The optimal wavelength for diazirine photo-activation is around $340 \mathrm{~nm}$. Avoid using UV lamps that emit light at $254 \mathrm{~nm}$ as this wavelength causes cell damage. Samples irradiation conditions should be optimized depending on UV lamp power and on the distance between the lamp and the sample. UV irradiation time should be less than 15 minutes for crosslinking of live cells. For efficient UV irradiation, use uncovered cell culture dishes and place the lamp directly above samples placed on ice.

5 For a better separation of $\mathrm{P} 2 \mathrm{X}$ complexes during electrophoresis, use precast gradient gels (such as 4 to $12 \%$ gradient).

6 Overexpression of P2X subunits might be toxic for cells. Minimize cytotoxicity by using low DNA amounts and low transfection reagent volume.

7 Prepare crosslinker solution immediately before use. 
8 In order to minimize plasma membrane receptor internalization, use cold buffers (at $4^{\circ} \mathrm{C}$ ) and keep cell dishes on ice during the crosslinking step.

9 Adjust incubation time to the UV lamp power.

10 Crosslinkers with disulfide bond within the spacer arm will be cleaved using reducing agent such as $\beta$-mercaptoethanol 


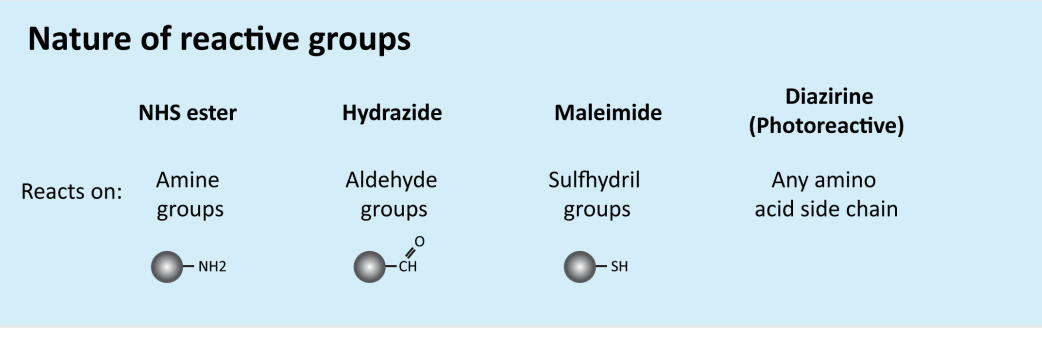

\section{Homobifunctionnal or heterobifunctionnal}

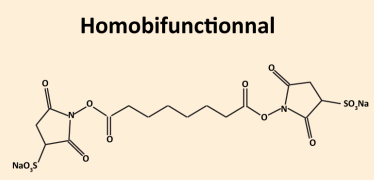

$\mathrm{BS}^{3}: 2$ NHS ester groups
Heterobifunctionnal

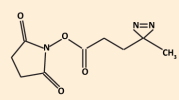

SDA : NHS ester group + Diazirine group

\section{Length (and composition) of the spacer arm}

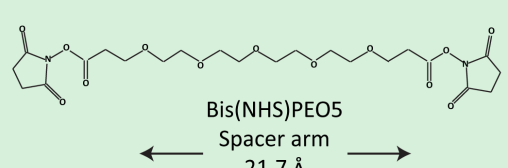

Spacer arm

$21.7 \AA$

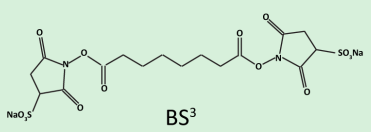

$11.4 \AA$

\section{Conjugated product cleavable or not}

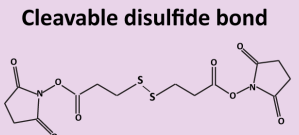

DSP

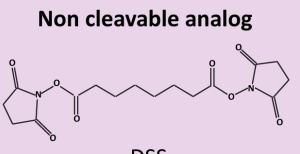

DSS

\section{Reagent solubility / membrane permeability}

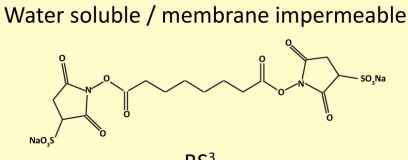

$\mathrm{BS}^{3}$
DMSO soluble / membrane permeable analog

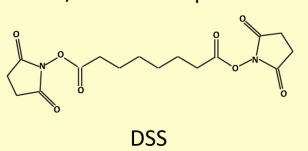

Figure 1: Overview of the main features of protein crosslinkers. This figure illustrates the 5 main features of protein crosslinkers and provides examples of reagents for each category. 
A
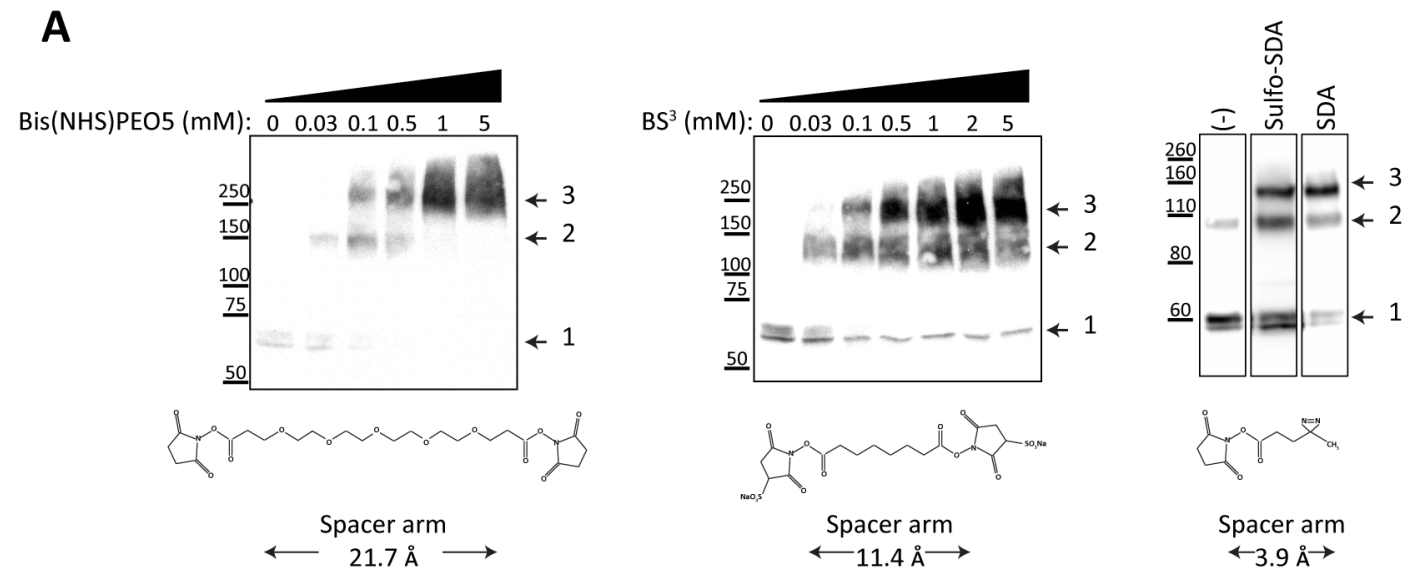

B

C
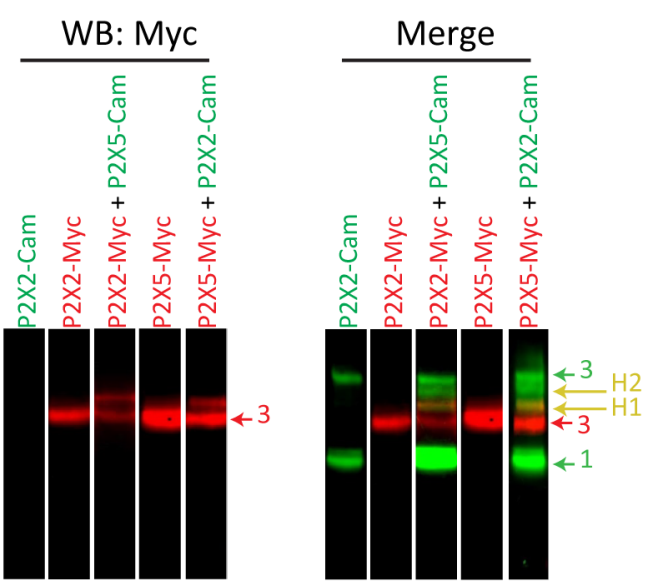

Figure 2: Analysis of P2X receptor quaternary structure by protein crosslinking. A, trimeric architecture of homomeric P2X2 receptor is revealed by different crosslinkers. HEK293 cells expressing P2X2 subunits were incubated with increasing concentration of crosslinkers differing by their chemical reactivity (homo-vs hetero-bifunctionnal), the length of their spacer arm and their membrane permeability. The structure of each crosslinker is represented below the corresponding WB. The numbers located at the right of each WB indicate the presence of monomers, dimers and trimers. B, Homomeric receptors

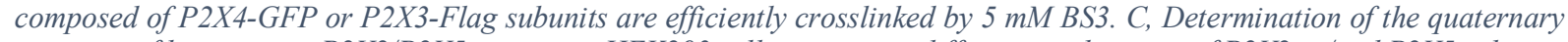
structure of heteromeric $P 2 X 2 / P 2 X 5$ receptors. HEK293 cells expressing different combination of $P 2 X 2$ or/and $P 2 X 5$ subunits fused to either small tag (Myc tag) or YC3.1 cameleon protein (Cam) were incubated with $5 \mathrm{mM}$ BS3. Complexes were separated by Western Blot and revealed using sequentially GFP (pseudo-colored in green) and Myc antibodies (pseudo-colored in red). Overlay of the two pictures revealed the presence of homotrimers and two heteromers (H1 and H2) corresponding to two different subunit stoichiometries. The presence of monomeric P2X2-Cam species likely represents intracellular pool of the subunits whose trafficking is impaired by the fusion partner.

\section{References}

1. Nicke A, Baumert HG, Rettinger J, Eichele A, Lambrecht G, Mutschler E, Schmalzing G (1998) P2X1 and $P 2 X 3$ receptors form stable trimers: a novel structural motif of ligand-gated ion channels. EMBO J 17 (11):3016-3028. doi:10.1093/emboj/17.11.3016

2. Barrera NP, Ormond SJ, Henderson RM, Murrell-Lagnado RD, Edwardson JM (2005) Atomic force microscopy imaging demonstrates that $\mathrm{P} 2 \times 2$ receptors are trimers but that $\mathrm{P} 2 \mathrm{X} 6$ receptor subunits do not oligomerize. J Biol Chem 280 (11):10759-10765. doi:10.1074/jbc.M412265200 3. Mio K, Kubo Y, Ogura T, Yamamoto T, Sato C (2005) Visualization of the trimeric P2X2 receptor with a crown-capped extracellular domain. Biochem Biophys Res Commun 337 (3):998-1005. doi:10.1016/j.bbrc.2005.09.141 
4. Kawate T, Michel JC, Birdsong WT, Gouaux E (2009) Crystal structure of the ATP-gated P2X(4) ion channel in the closed state. Nature 460 (7255):592-598. doi:10.1038/nature08198

5. Ennion SJ, Evans RJ (2002) Conserved cysteine residues in the extracellular loop of the human P2X(1) receptor form disulfide bonds and are involved in receptor trafficking to the cell surface. Mol Pharmacol 61 (2):303-311

6. Wickert LE, Blanchette JB, Waldschmidt NV, Bertics PJ, Denu JM, Denlinger LC, Lenertz LY (2013) The C-terminus of human nucleotide receptor P2X7 is critical for receptor oligomerization and Nlinked glycosylation. PLoS One 8 (5):e63789. doi:10.1371/journal.pone.0063789

7. Boumechache M, Masin M, Edwardson JM, Gorecki DC, Murrell-Lagnado R (2009) Analysis of assembly and trafficking of native P2X4 and P2X7 receptor complexes in rodent immune cells. J Biol Chem 284 (20):13446-13454. doi:10.1074/jbc.M901255200

8. Compan V, Ulmann L, Stelmashenko O, Chemin J, Chaumont S, Rassendren F (2012) P2X2 and P2X5 subunits define a new heteromeric receptor with P2X7-like properties. J Neurosci 32 (12):4284-4296. doi:10.1523/JNEUROSCI.6332-11.2012 